\title{
The Effect of Postural Correction and Exercise on Neck Pains in Cell Phone Users
}

\author{
Cep Telefonu Kullanıcılarında Postür Düzeltilmesi ve Egzersizin Boyun Ağrılarına Etkisi \\ (D) Ozan Soyer, (D) Zeynep Ülkü Akarırmak \\ istanbul University-Cerrahpaşa, Cerrahpaşa Faculty of Medicine, Department of Physical Medicine and Rehabilitation Istanbul, Turkey
}

\section{Abstract}

Objective: Using a cell phone in the head forward posture for a long time is a risk factor for the induction of trigger points (TP) and myofascial pain syndromes (MPS). The purpose of this study was to evaluate the association between cell phone use-related neck pain and MPS in the trapezius, sternocleidomastoideus and levator scapulae (LS) muscles as well as to determine an appropriate treatment approach. Materials and Methods: In total, 49 patients who had neck pain and reported using a cell phone were included in this study and divided randomly into two groups. Taut band existence and TP pain severity were evaluated in the trapezius, sternocleidomastoideus and LS muscles. In addition, neck pain severity and range of motion (ROM) were assessed. Group 1 received a structured exercise programme and posture correction advice, whereas group 2 did not receive any treatment. The patients were re-evaluated again after 1 month, and these parameters were compared with those at the first examination.

Results: A total of 47 patients completed this study. In group 1, the neck pain score was found to be significantly decreased ( $p<0.001)$, and the taut band of the right LS muscle to have significantly disappeared $(p=0.004)$. A significant decrease in TP pain severity was found on the 2nd point of the left sternocleidomastoideus ( $p=0.039)$, left trapezius ( $p=0.031)$, and right $L S(p=0.012)$ muscles. In addition, a borderline decrease in pain was found in the $2^{\text {nd }}$ point of the left LS muscle in group 1, although it did not reach statistical significance ( $\left.p=0.056\right)$. On the other hand, there were no significant changes in terms of neck pain score, taut band existence and TPs pain severity in group 2 . Pain and limitation of ROM showed no significant difference between the first and second examinations in both groups.

Conclusion: Limiting the duration of mobile phone usage, performing regular exercises and correcting the head forward position by increasing awareness can be helpful in preventing the development of text neck syndrome.

Keywords: Cell phone, neck pain, trapezius, sternocleidomastoideus, levator scapulae, trigger points, exercise, text neck syndrome

\section{Öz}

Amaç: Yanlış postürde uzun süreli cep telefonu kullanımı, tetik nokta (TN) ve miyofasiyal ağı sendromu (MAS) oluşumu açısından risk oluşturmaktadır. Bu çalışmanın amacı trapez, sternokleidomastoid ve levator skapula (LS) kaslarındaki cep telefonu kullanımı ilişkili boyun ağrısı ve MAS arasındaki ilişkiyi değerlendirmek ve doğru tedavi yaklaşımını belirlemektir.

Gereç ve Yöntem: Bu çalışmaya boyun ağrısı olan ve cep telefonu kullanan 49 hasta katıldı ve randomize olarak iki gruba ayrıldı. Boyun ağrısı şiddeti, boyun hareket açıklığı ve trapez, sternokleidomastoid ve LS kaslarında gergin bant varlığı ile TN ağrı şiddeti değerlendirildi. Grup 1'deki hastalara yapılandırılmış boyun egzersizleri ve postür düzeltme önerileri verilirken, grup 2'deki hastalar herhangi bir tedavi almadı. Bir ay sonucunda hastalar yukarıdaki parametreler açısından tekrar değerlendirildi.

Bulgular: Toplamda 47 hasta araştırmayı tamamladı. Grup 1'de boyun ağrısında $(p<0,001)$ ve sağ LS'de bulunan gergin bantlarda anlamlı bir azalma görüldü $(p=0,004)$. Ayrıca grup 1'de sol sternokleidomastoid 2 . noktasında $(p=0,039)$, sol trapez 2 . noktasında ( $p=0,031)$, ve sağ $L S$ 2. noktasında $(p=0,012)$ TN ağrı şiddetinde anlamlı azalma bulundu; ayrıca sol LS 2 . noktasında ağı şiddetinde sınıra yakın bir azalma bulunsa da bu azalma anlamlı bulunmadı $(p=0,056)$. Buna karşın grup 2'de boyun ağısı şiddeti, gergin bant varlığı ve TN ağrı şiddeti açısından anlamlı bir değişim tespit edilmedi. Ayrıca iki grupta da boyun hareket açıklığı muayenesi sırasında oluşan ağrı ve kısıtııık açısından anlamlı bir fark saptanmadı.

Sonuç: Cep telefonu kullanımına bağlı boyun ağıısı ve MAS gelişen hastalarda farkındalığı artırarak, text neck sendromu gelişimini önlemek için telefon kullanımının kısıtlanması, düzenli egzersiz yapııması ve telefon kullanımı sırasında doğru boyun postürünün sağlanması önerilmektedir. Anahtar kelimeler: Cep telefonu, boyun ağrısı, trapez, sternokleidomastoid, levator skapula, tetik nokta, egzersiz, text neck sendromu

Address for Correspondence/Yazışma Adresi: Ozan Soyer MD, İstanbul University-Cerrahpaşa Cerrahpaşa Faculty of Medicine, Department of Physical Medicine and Rehabilitation İstanbul, Turkey

Phone: +90 2124143000 E-mail: ozansoyer2@gmail.com ORCID ID: orcid.org/0000-0002-2245-7293 Received/Geliş Tarihi: 31.08.2019 Accepted/Kabul Tarihi: 08.11.2019 


\section{Introduction}

Neck pain is a major musculoskeletal complaint in the young population. The overall prevalence of neck pain in the general population was found to be $23.1 \%$ (1). Myofascial pain syndromes (MPS) were defined as one of the leading causes of neck and thoracic pain (2). MPS are characterized by trigger points (TP), taut bands, pressure sensitivity, and referred pain (3).

Using a cell phone in abnormal posture for a long time puts increased strain on neck muscles and causes the induction of TPs and MPS. It was also reported that avoiding the aggravating factors had a significant role in the prevention or worsening of MPS (4). In the neutral position of the head, which is 0 degrees, the weight carried by the neck is approximately 5 kilograms $(\mathrm{kg})$. This weight increases to nearly $12 \mathrm{~kg}$ with flexion of the head for 15 degrees, $18 \mathrm{~kg}$ with 30 degrees, $22 \mathrm{~kg}$ with 45 degrees and $27 \mathrm{~kg}$ with 60 degrees (5).

In the last years, the increased rate of cell phone usage and prolongation of using periods are responsible for increased neck muscle-related complaints. As a result, long-term fatigue, acute and chronic pain of the musculoskeletal system, and postural changes are detected in patients. If this condition is left untreated, it may be responsible for permanent changes such as flattening of the cervical spinal curve, spinal misalignment, and early spinal degenerations (6).

Along with steadily increasing in their usage, cell phones are becoming more and more important in our lives. As a result of that "text neck" which is the term for cervical spinal degeneration resulting from frequent forward head flexion while looking down at the of mobile devices, is becoming more common (7). According to a recent study, $79 \%$ of the population between the age of 18-44 spend 2 hours without their cell phones during their waking hours (6). Furthermore, $75 \%$ of the world's population spends hours while hunched over their handheld devices with their heads flexed forward (7).

Relationship between cell phone using and neck complaints has been shown by previous studies. Gustafsson et al. (8) found a relationship between text messaging and the neck/upper back pain. Berolo et al. (9) also found an association between cell phone using and pain in the neck and shoulder area.

Awareness about text neck syndrome was found to be very low in the population. According to a recent study, only $8 \%$ of the population was aware of text neck syndrome, $65 \%$ of them had never heard about it, while $27 \%$ reported having heard about it but did not know what it was. Also, 75\% of these patients stated that although they thought this syndrome is preventable, they did not know the method for prevention (10). These results show that people should be informed about text neck syndrome and prevention methods.

In our study, three of the frequently involved muscles, trapezius, sternocleidomastoideus and levator scapulae (LS) were evaluated due to their essential functions. The trapezius muscle is one of the primary responsible muscle for posture, perceived neck/shoulder pain intensity, and muscle tenderness (11). The sternocleidomastoideus frequently contains multiple TPs and is responsible for flexion of head and neck. LS is also one of the primary muscles for developing TP and neck pain. TPs in LS is usually responsible for "stiff neck" (markedly limited rotation) (3). The correlation between cervical posture and TPs were addressed in a previous study, and a significant increase in TPS of the LS was reported in chronic neck pain patients (12). The function of LS is to help the extension and rotation of the neck (3). In addition to the mentioned features of these muscles, their accessibility during the physical examination was considered for their choice in our study.

In this study, we aimed to increase awareness among the population and prevent text neck syndrome. Another goal of this study was to evaluate the association between cell phone use related-neck pain and MPS in trapezius, sternocleidomastoideus and LS muscles as well as determining an appropriate treatment approach by providing a structured exercise program and posture correction advice.

\section{Materials and Methods}

This study was carried out at the İstanbul University-Cerrahpaşa, Cerrahpaşa Faculty of Medicine, Department of Physical Medicine and Rehabilitation, İstanbul, Turkey. Approval was obtained from the İstanbul University-Cerrahpaşa, Cerrahpaşa Faculty of Medicine Ethics Committee. A total of 49 patients (21 female and 28 male) who were cell phone users and complained of neck pain attended this research. Occupations of the patients included desk workers and students.

Inclusion criteria were neck pain complaint, using a cell phone for at least two hours per day for five years and being between 15 and 40 years old.

Exclusion criteria were previous neck-head trauma, history of surgical intervention in the neck area, neurological deficit, severe neck pain which required medical treatment, cervical disc disease with radiculopathy, inflammatory or malignant type of pain, and systematic diseases.

Patients who applied to the outpatient clinic of our department with complaints of musculoskeletal system pain of different regions were evaluated. Those who had neck pain and fulfilled inclusion and exclusion criteria were determined to be suitable patients for our clinical study. The patients were randomly divided into two groups as group 1 [treatment group $(n=21)$ ], and group 2 [control group $(n=28)$ ]. Patients in group 1 received a structured exercise program and verbal as well as written posture correction advice, while group 2 patients did not receive any treatment.

Before the examination, all patients were informed in detail about the study and written consent forms were obtained. The examination consisted of four parts, including medical history, inspection, palpation, and neck range of motion (ROM) examination. 
All examinations were performed simultaneously by an intern and a physiatrist. Patients' history was asked in detail and age, body mass index (BMI) occupation, daily usage of cell phone and computer, number of years since regular cell phone using, duration of pain, pain characteristic and reference pattern, aggravating and alleviating factors, position during cell phone use, sport activity and smoking history were recorded.

Pain severity was measured by the Visual Analog scale (VAS) during the first examination and second examination which is one month later. Also, VAS measurements were saved as millimeters.

During the inspection, patients were evaluated for shoulder asymmetry, cervical lordosis, and dorsal postural deformities.

During palpation, two different points of sternocleidomastoideus

(Figure 1), three different points of trapezius (Figures 2.1, 2.2)

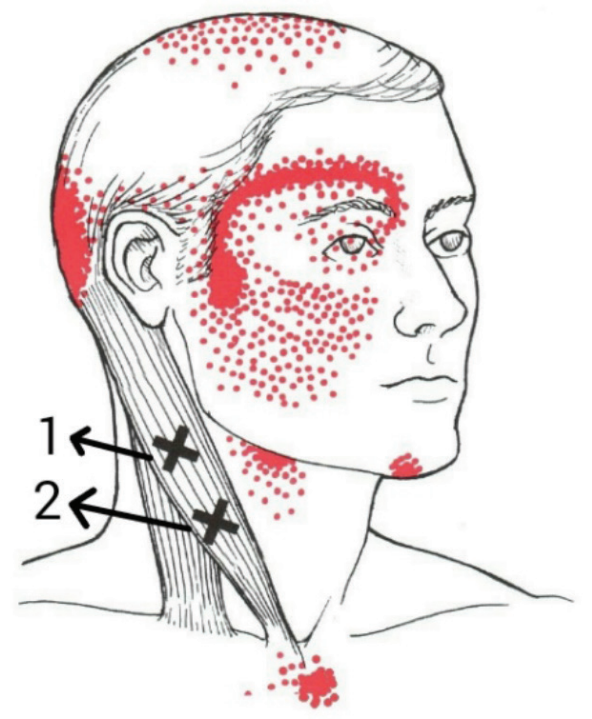

Figure 1. M. sternocleidomastoideus $1^{\text {st }}$ and $2^{\text {nd }}$ trigger points (12)

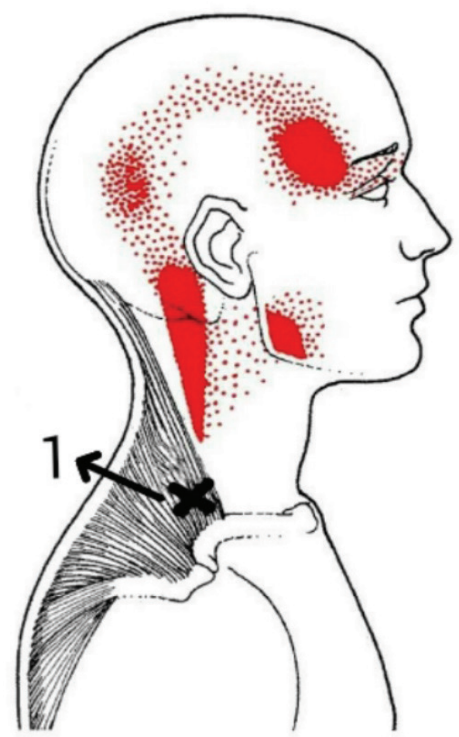

Figure 2.1. M. trapezius $1^{\text {st }}$ trigger point (12) and two different points of LS (Figure 3) were palpated and evaluated in terms of taut muscle bands and TP existence. While pression of these points, patients were asked to classify TP pain severity as grade 1 (mild pain), grade 2 (moderate pain) or grade 3 (severe pain).

During the neck ROM examination patients were assessed for pain and limitation in neck movements. Patients in group 2 were instructed to continue their regular life and not to receive any additional medication or treatment.

Patients in group 1 received a structured, exercise program consisting of neck muscles stretching and posture exercises also they were informed to perform exercises as 10 repeats and 2 sets in every day. In addition to exercises, they received advice for posture correction and limitations during cell phone usage. Neck exercises compromised neck rotation (Figure 4), isometric

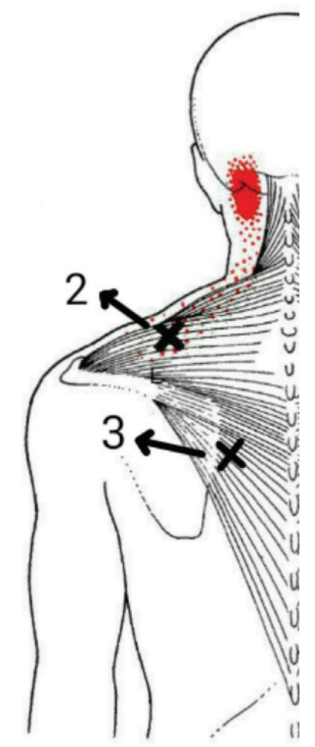

Figure 2.2. M. trapezius $2^{\text {nd }}$ and $3^{\text {rd }}$ trigger points (12)

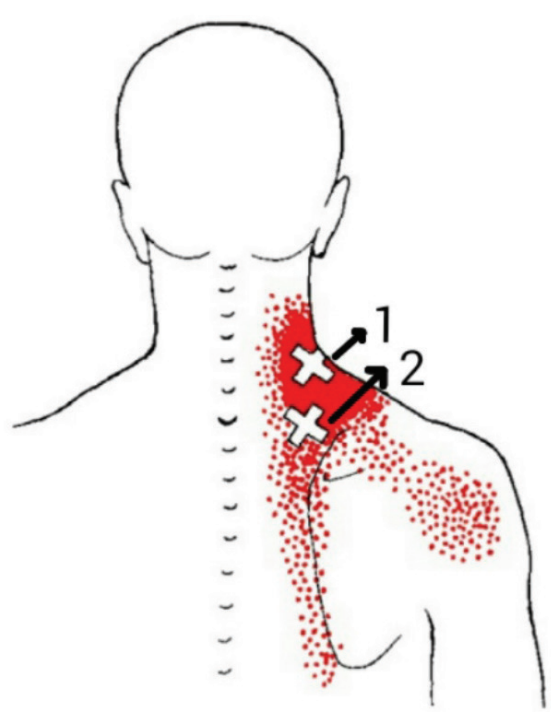

Figure 3. M. levator Scapulae $1^{\text {st }}$ and $2^{\text {nd }}$ trigger points (12) 

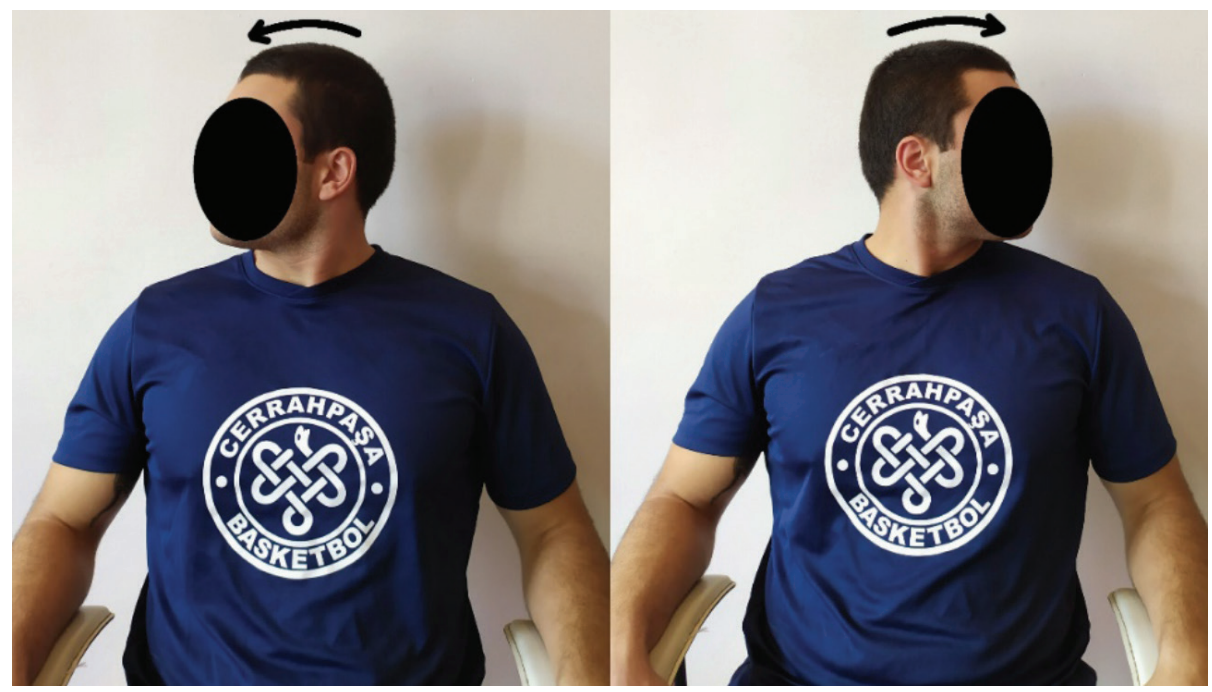

Figure 4. Neck rotation exercise

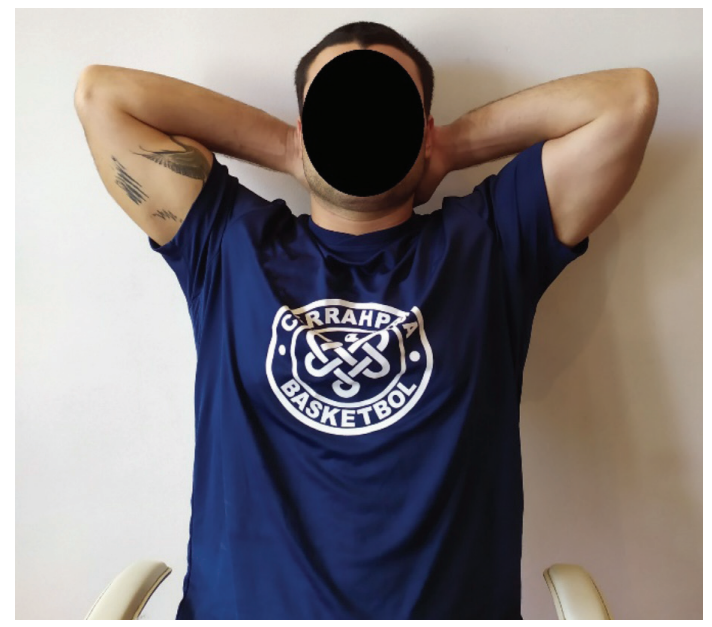

Figure 5. Isometric neck extension exercise

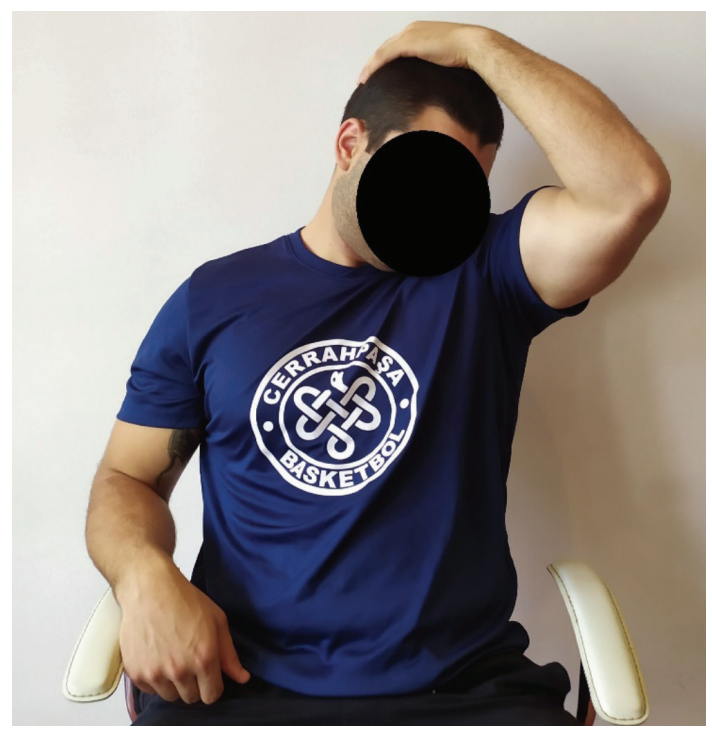

Figure 6. Levator scapulae stretch neck extension (Figure 5), LS stretch (Figure 6), lateral neck stretch in standing (Figure 7) and lying position (Figure 8), standing chest stretch (Figure 9), shoulder roll (Figure 10), corner chest stretch (Figure 11), and trapezius muscle stretch in lying position (Figure 12).

The written posture advice was:

- While using a cell phone, personal computer and other electronic devices please hold them at eye level.

- Please give a break in every 20 minutes during using of these devices.

- While using big and heavy electronic devices such as Tablets and large cell phones, please hold them with both hands.

- During reading books or newspapers please hold them at eye level.

- While using cell phone, avoid high repetitive typing and scrolling the screen for a long time.

- Try not to hunch forward during electronic devices.

Additionally, patients in group 1 were informed about a mobile phone application which warns about changes in the head posture by a notification.

All patients were informed to reach the physician immediately if any adverse events or a significant increase in pain severity occurred.

One month after the first examination, patients were called for control. In the follow-up examination, patients' pain severity was measured again by VAS. Taut bands, TPs, and neck ROM were assessed.

\section{Statistical Analysis}

Mc Nemar test was utilized to determining significance of taut band existence and pain or limitation during ROM assessment in groups. For evaluating VAS Pain score, Mann-Whitney $U$ test was applied. Wilcoxon Signed Ranks test was used for determination of pain severity in TPS. SPSS 21.0 (IBM, USA) was used for all the statistical analyses and statistical significance was assumed when $\mathrm{p}$-value was lowered than 0.05 . 


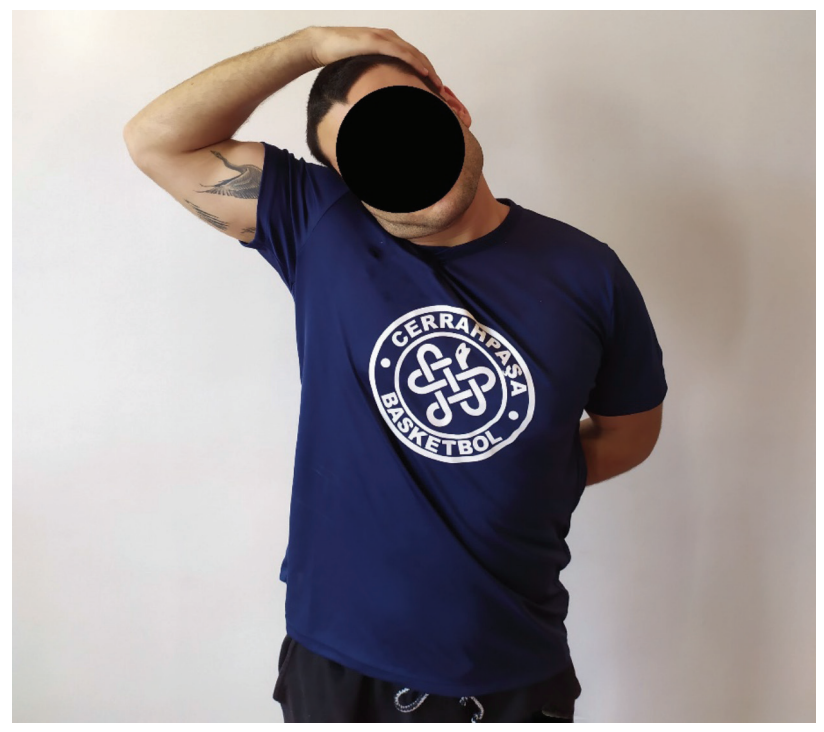

Figure 7. Lateral neck stretch in standing position

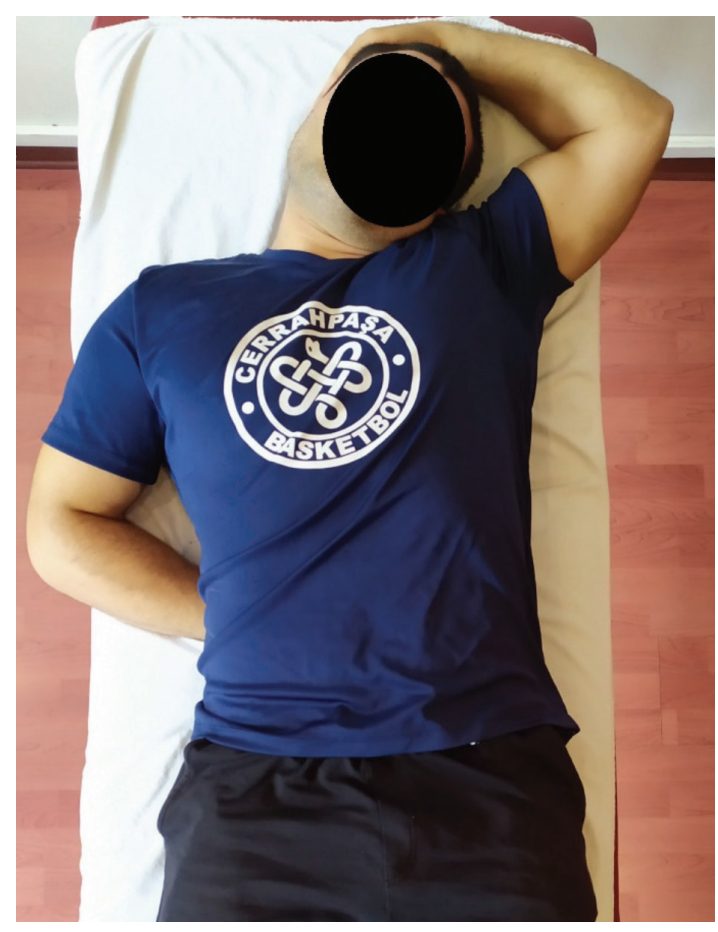

Figure 8. Lateral neck stretch in lying position

\section{Results}

From a total of 49 patients, 21 patients in group 1 and 26 patients in group 2 completed the study. Two patients from group 2 were eliminated. The first patient was eliminated due to the diagnosis of fibromyalgia syndrome and the second one was eliminated because he had to take additional medicational treatment. Patient demographic data and pain characteristics were recorded during the first examination and they were shown in Table 1. Males compromised $57.4 \% \quad(n=27)$ and females compromised $42.6 \%(n=20)$ of patients. The mean

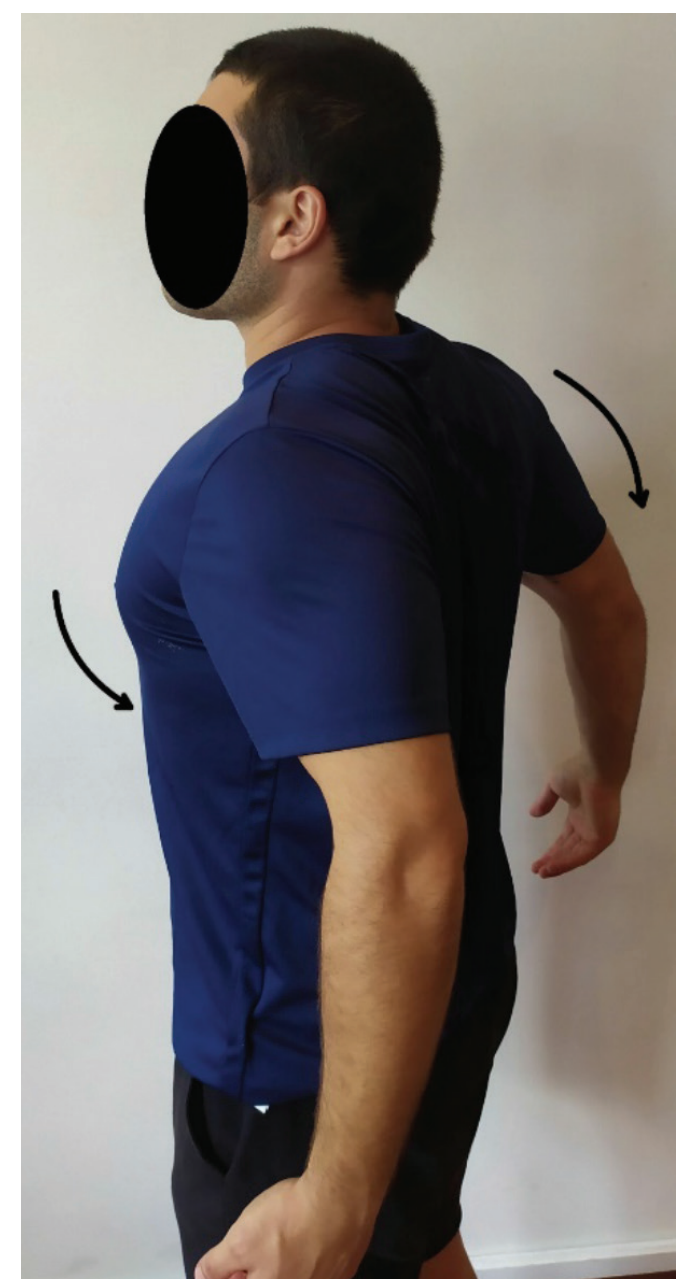

Figure 9. Standing chest stretch

age of participants was $27.6 \pm 7.4$ [mean \pm standard deviation $(\mathrm{SD})]$, and the mean BMI was 23.5 \pm 3.1 (mean $\pm \mathrm{SD}$ ). All patients complained of a mechanical type of neck pain. $63.8 \%$ of patients described referral of pain to different regions, especially to shoulders, head, back, and arms.

In the physical examination, cervical lordosis was found to be decreased in $55.3 \%$ of patients. Shoulder asymmetry, especially depression of one shoulder, was inspected in $30.4 \%$ of patients. Neck pain severity was assessed by VAS pain score in the beginning and after one month. Pain score in group 1 was $43.3 \pm 16.3$ (mean \pm SD) in the first assessment, while it was $21.9 \pm 13.3$ (mean \pm SD) in the second assessment. According to VAS neck pain score results, a significant decrease was found in group $1(p<0.001)$. In contrast, there were no significant changes found in group $2(p=0.123)$. Group 2 pain severity scores were recorded as $37.0 \pm 16.9$ (mean \pm SD) in the first and $30.3 \pm 15.3$ (mean \pm SD) in the second assessment (Table 2). Patients were evaluated in terms of the existence of the taut band and TP pain severity during palpation. In group 1, only the taut band of right LS had significantly disappeared ( $p=0.004)$; 


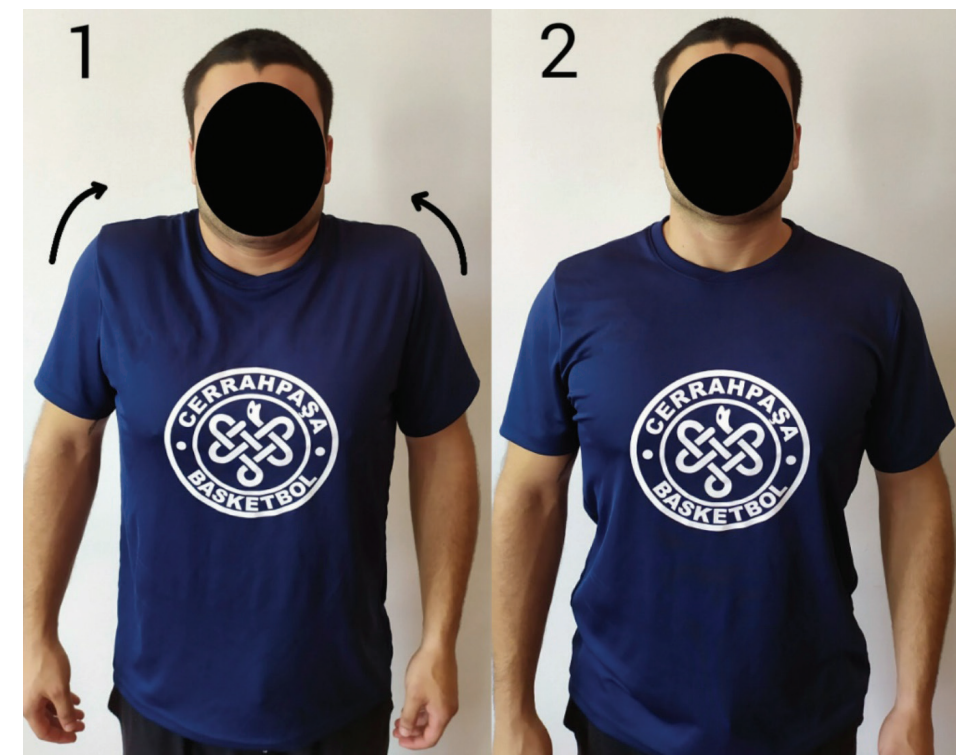

Figure 10. Shoulder roll exercise

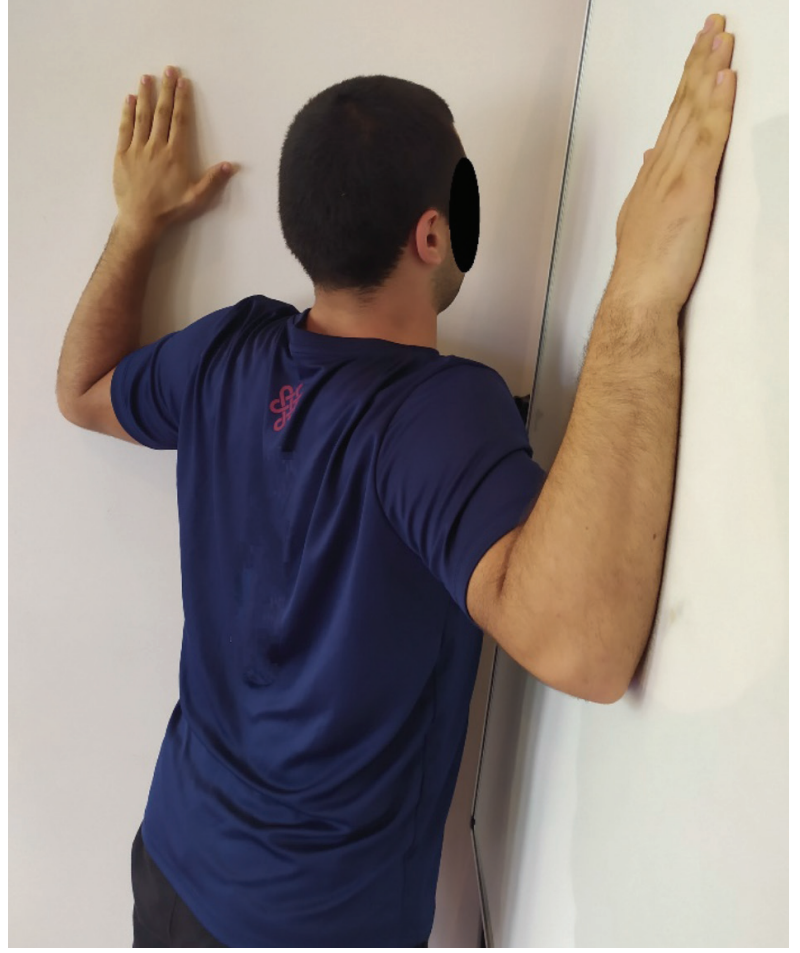

Figure 11. Corner chest stretch

however, there were no significant changes in group 2 with regard to examined muscles.

TPs pain severity was found to be significantly decreased at the $2^{\text {nd }}$ point of the left sternocleidomastoideus ( $p=0.039$ ), left trapezius ( $p=0.031)$, and right $L S(p=0.012)$ muscles in group 1 . In the $2^{\text {nd }}$ point of the left side in LS, pain decrease was found borderline, although it did not reach statistical significance (Table $3)$. There were no significant changes with regards to TP pain in group 2 (Table 4).
Pain and limitation during neck ROM examination revealed no significant changes between the first and second examination in group 1 and 2.

\section{Discussion}

In our study, we aimed at describing the relationship between neck pain, MPS and treatment outcome in mobile phone users. Neck pain and its relationship to using electronic devices and the correlation with MPS have been discussed extensively. This study measured changes in patients' VAS neck pain score, TP's pain, taut band existence, and neck ROM and compared results in treatment and control groups.

In our study, students (44.7\%) and desk workers (55.3\%) constituted the population. Along with using electronic devices frequently and spending extended time with head forward posture, neck pain complaint is becoming very common among students and desk workers in the population. According to recent studies, $46 \%$ of students (13) and 50 to $60 \%$ of desk workers reported neck pain (14). Our findings and previous research's results show that patients who belong to these two occupation groups should be informed by physicians about neck pain development and effective prevention methods.

Most cases with neck pain run an episodic course over a lifetime and, thus, relapses are frequent (1). In 91.5\% ( $n=43$ ) of our patients, the duration of neck pain was over six months, that denoted if neck pains are not treated adequately they tend to develop chronic musculoskeletal pain condition.

Spending a long time using a cell phone, frequently talking, texting, and gaming was described as a risk factor for developing neck pain $(9,15,16)$

In this study, $46.3 \%$ of patients reported that their daily phone usage was between 3 to 6 hours. This finding was consistent with the study conducted by Berolo et al. (9), who reported a mean of $4.6 \pm 5.6$ (mean \pm SD) hours. $55.3 \%$ of our patients 
Table 1. Patient data and pain characteristics

\begin{tabular}{|c|c|c|c|}
\hline Age (years) & $27.6 \pm 7.4$ & \multicolumn{2}{|c|}{ Number of years since regular cell phone using (years) } \\
\hline Body mass index & $23.5 \pm 3.1$ & $<10$ & $36.2 \%(n=17)$ \\
\hline \multicolumn{2}{|l|}{ Gender } & $10-20$ & $55.3 \%(n=26)$ \\
\hline Female & $42.6 \%(n=20)$ & $20>$ & $8.5 \%(n=4)$ \\
\hline Male & $57.4 \%(n=27)$ & \multicolumn{2}{|c|}{ Daily phone usage (hours) } \\
\hline \multicolumn{2}{|l|}{ Occupation } & $<3$ & $29.8 \%(n=14)$ \\
\hline Student & $44.7 \%(n=21)$ & $3-6$ & $46.3 \%(n=22)$ \\
\hline Desk workers & $55.3 \%(n=26)$ & $>6$ & $21.3 \%(n=10)$ \\
\hline \multicolumn{2}{|l|}{ Referred pain } & \multicolumn{2}{|c|}{ Posture during phone use } \\
\hline Yes & $63.8 \%(n=30)$ & Sit and bend forward & $78.7 \%(n=37)$ \\
\hline No & $36.2 \%(n=17)$ & Lie on back & $8.5 \%(n=4)$ \\
\hline \multicolumn{2}{|c|}{ Onset of pain (months) } & Both & $12.8 \%(n=6)$ \\
\hline$<1$ & $4.3 \%(n=2)$ & \multicolumn{2}{|c|}{ Pain aggrevating posture during phone use } \\
\hline $1-6$ & $4.3 \%(n=2)$ & Sit and bend forward & $84.6 \%(n=22)$ \\
\hline$>6$ & $91.5 \%(n=43)$ & Lie down & $7.7 \%(n=2)$ \\
\hline \multicolumn{2}{|c|}{ Is pain continuous or intermittent } & Both & $7.7 \%(n=2)$ \\
\hline Continiuous & $36.2 \%(n=17)$ & \multicolumn{2}{|c|}{ Daily personal computer usage (hours) } \\
\hline Intermittent & $63.8 \%(n=30)$ & $<3$ & $36.2 \%(n=17)$ \\
\hline \multicolumn{2}{|c|}{ Frequency of pain (in one week) } & $3-6$ & $10.6 \%(n=5)$ \\
\hline$>3$ & $41.2 \%(n=14)$ & $>6$ & $53.2 \%(n=25)$ \\
\hline$<3$ & $58.8 \%(n=20)$ & \multicolumn{2}{|l|}{ Smoking } \\
\hline \multicolumn{2}{|c|}{ Aggravating factors of pain } & Yes & $32.6 \%(n=15)$ \\
\hline Phone using & $58.7 \%(n=27)$ & No & $67.4 \%(n=31)$ \\
\hline Others & $41.3 \%(n=19)$ & \multicolumn{2}{|l|}{ Regular sport activities } \\
\hline \multicolumn{2}{|c|}{ Alleviating factors of pain } & Yes & $44.7 \%(n=21)$ \\
\hline Stretching & $46.9 \%(n=15)$ & No & $55.3 \%(n=26)$ \\
\hline Resting & $37.5 \%(n=12)$ & \multicolumn{2}{|l|}{ Cervical lordosis } \\
\hline \multirow[t]{3}{*}{ Both } & $15.6 \%(n=5)$ & Decreased & $55.3 \%(n=26)$ \\
\hline & & Normal & $44.7 \%(n=21)$ \\
\hline & & Shoulder asymmetry & $30.4 \%(n=14)$ \\
\hline
\end{tabular}

stated that they have been using a cell phone for 10 to 20 years. Hegazy et al. (16), stated a shorter average duration of owning a cell phone $[7.8 \pm 1.9$ years (mean $\pm S D$ )]. The mean age of our patients $[27.6 \pm 7.4$ years (mean \pm SD)] was older than in Hegazy et al.'s (16) study [21 \pm 1.1 years (mean \pm SD)], which could elucidate this difference.

Along with cell phones becoming more popular, neck pain complaints keep increasing. In our study, $58.7 \%$ of patients stated that cell phone use caused or increased their neck pain. Complaints due to using mobile devices for a long time were studied by different researchers, and the most common symptom was found to be neck pain. The results for frequency of neck pain symptom was reported in different studies to change between 40.9\% [Shan et al. (17)], 55.8\% [Kim and Kim. (18)], 68\% [Berolo et al. (9)], and 71.2\% [Alzarea and Patil (19)]. We found that the most frequently described posture by our patients during phone use was sitting and bending forward position (78.7\%). Also, these patients stated that this posture was responsible for the aggravation of neck pain (84.6\%). Gold et al. (20), observed almost two-thirds of their patients were using a cell phone in neck flexed posture. This finding was consistent with our results. The relationship between flexed neck posture and neck pain has also been studied by different researchers. Gustafsson et al. (8) mentioned that two prospective cohort studies have shown an increased risk for neck or neck/shoulder pain during work with neck flexion position. Two recent studies reported that an increase in cervical flexion degree caused a significant increase in muscle fatigue and pain in the upper trapezius muscle $(21,22)$. Also, Syamala et al. (23) stated that holding cell phone at eye level with proper body support during usage can reduce the biomechanical stress in the neck and upper extremities. 


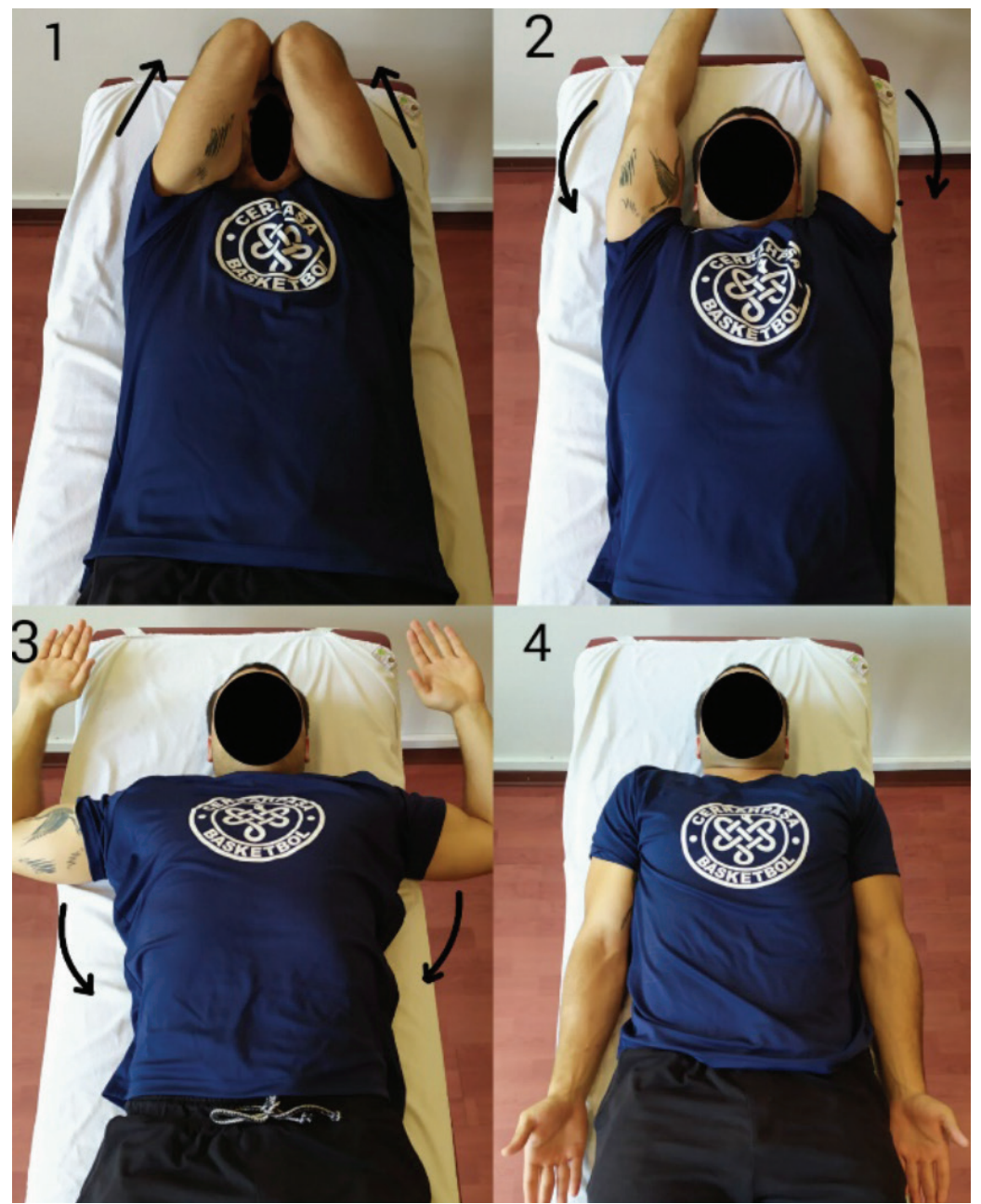

Figure 12. Trapezius muscle stretch in lying position

Table 2. Comparison of patients' Visual Analog scale neck pain score between the $1^{\text {st }}$ and $2^{\text {nd }}$ measurement

\begin{tabular}{|l|l|l|l|}
\hline & $\begin{array}{l}\text { 1st } \\
\text { Measurement }\end{array}$ & $\begin{array}{l}\text { 2nd } \\
\text { Measurement }\end{array}$ & \\
\cline { 2 - 4 } & $\begin{array}{l}\text { Mean } \pm \text { SD } \\
(\mathbf{m m})\end{array}$ & $\begin{array}{l}\text { Mean } \pm \text { SD } \\
(\mathbf{m m})\end{array}$ & *p \\
\hline Group 1 & $43.3 \pm 16.3$ & $21.9 \pm 13.3$ & $\mathrm{p}<0.001^{*}$ \\
\hline Group 2 & $37.0 \pm 16.9$ & $30.3 \pm 15.3$ & $\mathrm{p}=0.123$ \\
\hline
\end{tabular}

${ }^{*} p<0.05$, thereby indicating a significant difference in patients' Visual Analog scale neck pain score, SD: Standard deviation

In our study, we did not find a significant change in patients' limitation and pain during neck ROM examination in the two groups. However, Kong et al. (24) found a significant increase in neck ROM after four weeks of modified cervical exercise program. A possible explanation of this difference could be that our patients did not perform exercises on a regular basis. Another explanation could be that limitation in neck ROM was not an inclusion criterion in our study, and therefore, a change could not be detected.
Cervical lordosis was found to be decreased in 55.3\% ( $\mathrm{n}=26)$ of the patients. According to a recent research, cell phone use causes a decrease in cervical lordosis (25). Our findings were consistent with that of Ögrenci et al. (26), who reported a significant correlation between decreased cervical lordosis and the duration of phone usage.

After a one-month exercise program and posture correction advice, we found a significant decrease in VAS neck pain score $(p<0.05)$ in the treatment group. Jagdhari et al. $(2)$, evaluated pain score by using VAS at the 1 st, $30^{\text {th }}$, and $60^{\text {th }}$ days and found a significant decrease in exercise group in consistency with our result.

TPs and taut bands were present in different locations and different muscles in all of our patients. TPs are often located in muscles in the neck and thoracic region, also secondary TPs development is quite often $(7,27)$. Our results showed that the presence of TPs in the sternocleidomastoideus was associated with the presence of TPs in the trapezius muscle and the LS. These findings were parallel to Fernández-de-las-Peñas et al.'s (28) study.

In our study after patients performed the exercise program and followed posture advice for one month, TPs pain severity was 
Table 3. Group 1 patients' trigger point pain severity and significance of difference between 1 st and $2^{\text {nd }}$ examinations in different locations

\begin{tabular}{|c|c|c|c|c|c|c|c|c|c|}
\hline \multirow[b]{2}{*}{ Trigger point location } & \multicolumn{4}{|c|}{ 1st Examination } & \multicolumn{4}{|c|}{$2^{\text {nd }}$ Examination } & \multirow[b]{2}{*}{${ }^{*} p$} \\
\hline & Painless & $\begin{array}{l}\text { Mild } \\
\text { pain }\end{array}$ & $\begin{array}{l}\text { Moderate } \\
\text { pain }\end{array}$ & $\begin{array}{l}\text { Severe } \\
\text { pain }\end{array}$ & Painless & $\begin{array}{l}\text { Mild } \\
\text { pain }\end{array}$ & $\begin{array}{l}\text { Moderate } \\
\text { pain }\end{array}$ & $\begin{array}{l}\text { Severe } \\
\text { pain }\end{array}$ & \\
\hline $\begin{array}{l}\text { M. sternocleidomastoideus } \\
\text { right } 1^{\text {st }}\end{array}$ & $\begin{array}{l}52.4 \% \\
(n=11) \\
\end{array}$ & $\begin{array}{l}14.3 \% \\
(n=3)\end{array}$ & $\begin{array}{l}23.8 \% \\
(n=5)\end{array}$ & $\begin{array}{l}9.5 \% \\
(n=2)\end{array}$ & $\begin{array}{l}76.2 \% \\
(n=16) \\
\end{array}$ & $\begin{array}{l}9.5 \% \\
(n=2)\end{array}$ & $\begin{array}{l}14.3 \% \\
(n=3)\end{array}$ & - & $p=0.176$ \\
\hline $\begin{array}{l}\text { M. sternocleidomastoideus } \\
\text { right } 2^{\text {nd }}\end{array}$ & $\begin{array}{l}52.4 \% \\
(n=11)\end{array}$ & $\begin{array}{l}23.8 \% \\
(n=5)\end{array}$ & $\begin{array}{l}14.3 \% \\
(n=3)\end{array}$ & $\begin{array}{l}9.5 \% \\
(n=2)\end{array}$ & $\begin{array}{l}76.2 \% \\
(n=16) \\
\end{array}$ & $\begin{array}{l}9.5 \% \\
(n=2)\end{array}$ & $\begin{array}{l}4.8 \% \\
(n=1)\end{array}$ & $\begin{array}{l}9.5 \% \\
(n=2)\end{array}$ & $p=0.092$ \\
\hline $\begin{array}{l}\text { M. sternocleidomastoideus } \\
\text { left } 1 \text { st }\end{array}$ & $\begin{array}{l}61.9 \% \\
(n=13)\end{array}$ & $\begin{array}{l}9.5 \% \\
(n=2)\end{array}$ & $\begin{array}{l}23.8 \% \\
(n=5)\end{array}$ & $\begin{array}{l}4.8 \% \\
(n=1)\end{array}$ & $\begin{array}{l}85.7 \% \\
(n=18)\end{array}$ & $\begin{array}{l}9.5 \% \\
(n=2)\end{array}$ & $\begin{array}{l}4.8 \% \\
(n=1)\end{array}$ & - & $p=0.388$ \\
\hline $\begin{array}{l}\text { M. sternocleidomastoideus } \\
\text { left } 2^{\text {nd }}\end{array}$ & $\begin{array}{l}52.4 \% \\
(n=11)\end{array}$ & $\begin{array}{l}28.6 \% \\
(n=6)\end{array}$ & $\begin{array}{l}14.3 \% \\
(n=3)\end{array}$ & $\begin{array}{l}4.8 \% \\
(n=1)\end{array}$ & $\begin{array}{l}90.5 \% \\
(n=19)\end{array}$ & $\begin{array}{l}9.5 \% \\
(n=2)\end{array}$ & - & - & $p=0.039$ * \\
\hline M. trapezius right $1^{\text {st }}$ & $\begin{array}{l}57.1 \% \\
(n=12) \\
\end{array}$ & $\begin{array}{l}14.3 \% \\
(n=3)\end{array}$ & $\begin{array}{l}28.6 \% \\
(n=6)\end{array}$ & - & $\begin{array}{l}52.4 \% \\
(n=11) \\
\end{array}$ & $\begin{array}{l}19.0 \% \\
(n=4)\end{array}$ & $\begin{array}{l}28.6 \% \\
(n=6)\end{array}$ & - & $p=0.717$ \\
\hline M. trapezius right $2^{\text {nd }}$ & $\begin{array}{l}33.3 \% \\
(n=7)\end{array}$ & $\begin{array}{l}28.6 \% \\
(n=6)\end{array}$ & $\begin{array}{l}23.8 \% \\
(n=5)\end{array}$ & $\begin{array}{l}14.3 \% \\
(n=3)\end{array}$ & $\begin{array}{l}42.9 \% \\
(n=9)\end{array}$ & $\begin{array}{l}23.8 \% \\
(n=5)\end{array}$ & $\begin{array}{l}19 \% \\
(n=4)\end{array}$ & $\begin{array}{l}14.3 \% \\
(n=3)\end{array}$ & $p=0.381$ \\
\hline M. trapezius right $3^{\text {rd }}$ & $\begin{array}{l}66.7 \% \\
(n=14) \\
\end{array}$ & $\begin{array}{l}14.3 \% \\
(n=3)\end{array}$ & $9.5 \%(n=2)$ & $\begin{array}{l}9.5 \% \\
(n=2)\end{array}$ & $\begin{array}{l}61.9 \% \\
(n=13)\end{array}$ & $\begin{array}{l}19 \% \\
(n=4)\end{array}$ & $\begin{array}{l}14.3 \% \\
(n=3)\end{array}$ & $\begin{array}{l}4.8 \% \\
(n=1)\end{array}$ & $p=0.509$ \\
\hline M. trapezius left 1 st & $\begin{array}{l}57.1 \% \\
(n=12)\end{array}$ & $\begin{array}{l}14.3 \% \\
(n=3)\end{array}$ & $\begin{array}{l}28.6 \% \\
(n=6)\end{array}$ & - & $\begin{array}{l}61.9 \% \\
(n=13)\end{array}$ & $\begin{array}{l}23.8 \% \\
(n=5)\end{array}$ & $\begin{array}{l}14.3 \% \\
(n=3)\end{array}$ & - & $p=0.959$ \\
\hline M. trapezius left $2^{\text {nd }}$ & $\begin{array}{l}42.9 \% \\
(n=9)\end{array}$ & $\begin{array}{l}23.8 \% \\
(n=5)\end{array}$ & $\begin{array}{l}23.8 \% \\
(n=5)\end{array}$ & $\begin{array}{l}9.5 \% \\
(n=2)\end{array}$ & $\begin{array}{l}76.2 \% \\
(n=16) \\
\end{array}$ & $\begin{array}{l}9.5 \% \\
(n=2)\end{array}$ & $\begin{array}{l}14.3 \% \\
(n=3)\end{array}$ & - & $p=0.031^{*}$ \\
\hline M. trapezius left $3^{\text {rd }}$ & $\begin{array}{l}61.9 \% \\
(n=13) \\
\end{array}$ & $\begin{array}{l}23.8 \% \\
(n=5)\end{array}$ & $\begin{array}{l}14.3 \% \\
(n=3)\end{array}$ & - & $\begin{array}{l}61.9 \% \\
(n=13) \\
\end{array}$ & $\begin{array}{l}23.8 \% \\
(n=5)\end{array}$ & $\begin{array}{l}14.3 \% \\
(n=3)\end{array}$ & - & $p=1$ \\
\hline LS right 1 st & $\begin{array}{l}66.7 \% \\
(n=14) \\
\end{array}$ & $\begin{array}{l}14.3 \% \\
(n=3)\end{array}$ & $\begin{array}{l}19 \% \\
(n=4)\end{array}$ & - & $\begin{array}{l}76.2 \% \\
(n=16) \\
\end{array}$ & $\begin{array}{l}14.3 \% \\
(n=3)\end{array}$ & $\begin{array}{l}9.5 \% \\
(n=2)\end{array}$ & - & $p=0.619$ \\
\hline LS right $2^{\text {nd }}$ & $\begin{array}{l}33.3 \% \\
(n=7)\end{array}$ & $\begin{array}{l}23.8 \% \\
(n=5)\end{array}$ & $\begin{array}{l}33.3 \% \\
(n=7)\end{array}$ & $\begin{array}{l}9.5 \% \\
(n=2)\end{array}$ & $\begin{array}{l}81 \% \\
(n=17)\end{array}$ & $\begin{array}{l}14.3 \% \\
(n=3)\end{array}$ & $\begin{array}{l}4.8 \% \\
(n=1)\end{array}$ & - & $p=0.012^{*}$ \\
\hline LS left 1st & $\begin{array}{l}57.1 \% \\
(n=12)\end{array}$ & $\begin{array}{l}19 \% \\
(n=4)\end{array}$ & $\begin{array}{l}23.8 \% \\
(n=5)\end{array}$ & - & $\begin{array}{l}66.7 \% \\
(n=14)\end{array}$ & $\begin{array}{l}14.3 \% \\
(n=3)\end{array}$ & $\begin{array}{l}19 \% \\
(n=4)\end{array}$ & - & $p=0.550$ \\
\hline LS left 2nd & $\begin{array}{l}33.3 \% \\
(n=7)\end{array}$ & $\begin{array}{l}23.8 \% \\
(n=5)\end{array}$ & $\begin{array}{l}42.9 \% \\
(n=9)\end{array}$ & - & $\begin{array}{l}57.1 \% \\
(n=12)\end{array}$ & $\begin{array}{l}4.8 \% \\
(n=1)\end{array}$ & $\begin{array}{l}38.1 \% \\
(n=8)\end{array}$ & - & $p=0.056$ \\
\hline
\end{tabular}

found to be significantly decreased at the $2^{\text {nd }}$ point of the left sternocleidomastoideus ( $p=0.039)$, left trapezius $(p=0.031)$, and right LS ( $p=0.012)$ muscles in group 1 . Also, the $2^{\text {nd }}$ point of the left side in LS $(p=056)$ pain decreased but did not reach statistical significance. There were no significant changes with regards to TPs pain in group 2. Taut bands in LS significantly disappeared in group $1(p<0.05)$. Also, Jagdhari et al.'s (2) study, detected a reduction in muscle tenderness in the exercise group. Additionally, decreased myofascial TP sensitivity in response to passive stretch in patients with myofascial head and neck pain was reported (29).

The strong point of our study was that despite many studies pointing out the correlation between neck pain and cell phone usage, only very few of them focused on treatment. In our study, the patients received a structured neck exercise program and recommendations for posture correction and limitations during cell phone usage. A follow-up examination of all patients was carried out after one month of treatment.

\section{Study Limitations}

The limitations of our study were that examinations were not performed blind. The other limitation was that exercises should be performed for two to three months to show optimal improvement. A prospective follow-up of patients for more prolonged periods could be advisable in future research studies.

\section{Conclusion}

Cell phone using rates have increased in recent years. As a result of this, the number of people who have cell phone use-related neck pain complaints has been on the rise. Limiting the duration of mobile phone usage and correcting forward head position by increasing awareness should be recommended. Furthermore, a structured neck exercise program performed on a regular basis also should be helpful to prevent the development and treatment of text neck syndrome. 


\begin{tabular}{|c|c|c|c|c|c|c|c|c|c|}
\hline \multirow[b]{2}{*}{ Trigger point location } & \multicolumn{4}{|c|}{ 1st Examination } & \multicolumn{4}{|c|}{$2^{\text {nd }}$ Examination } & \multirow[b]{2}{*}{$\mathbf{p}$} \\
\hline & Painless & $\begin{array}{l}\text { Mild } \\
\text { pain }\end{array}$ & $\begin{array}{l}\text { Moderate } \\
\text { pain }\end{array}$ & $\begin{array}{l}\text { Severe } \\
\text { pain }\end{array}$ & Painless & $\begin{array}{l}\text { Mild } \\
\text { pain }\end{array}$ & $\begin{array}{l}\text { Moderate } \\
\text { pain }\end{array}$ & $\begin{array}{l}\text { Severe } \\
\text { pain }\end{array}$ & \\
\hline $\begin{array}{l}\text { M. sternocleidomastoideus } \\
\text { right } 1^{\text {st }}\end{array}$ & $\begin{array}{l}65.4 \% \\
(n=17)\end{array}$ & $\begin{array}{l}3.8 \% \\
(n=1)\end{array}$ & $\begin{array}{l}26.9 \% \\
(n=7)\end{array}$ & $\begin{array}{l}3.8 \% \\
(n=1)\end{array}$ & $\begin{array}{l}50 \% \\
(n=13)\end{array}$ & $\begin{array}{l}19.2 \% \\
(n=5)\end{array}$ & $\begin{array}{l}26.9 \% \\
(n=7)\end{array}$ & $\begin{array}{l}3.8 \% \\
(n=1)\end{array}$ & $p=0.085$ \\
\hline $\begin{array}{l}\text { M. sternocleidomastoideus } \\
\text { right } 2^{\text {nd }}\end{array}$ & $\begin{array}{l}57.7 \% \\
(n=15)\end{array}$ & $\begin{array}{l}19.2 \% \\
(n=5)\end{array}$ & $\begin{array}{l}11.5 \% \\
(n=3)\end{array}$ & $\begin{array}{l}11.5 \% \\
(n=3)\end{array}$ & $\begin{array}{l}61.5 \% \\
(n=16)\end{array}$ & $\begin{array}{l}3.8 \% \\
(n=1)\end{array}$ & $\begin{array}{l}19.2 \% \\
(n=5)\end{array}$ & $\begin{array}{l}15.4 \% \\
(n=4)\end{array}$ & $p=0.321$ \\
\hline $\begin{array}{l}\text { M. sternocleidomastoideus } \\
\text { left } 1^{\text {st }}\end{array}$ & $\begin{array}{l}61.5 \% \\
(n=16)\end{array}$ & $\begin{array}{l}15.4 \% \\
(n=4)\end{array}$ & $\begin{array}{l}11.5 \% \\
(n=3)\end{array}$ & $\begin{array}{l}11.5 \% \\
(n=3)\end{array}$ & $\begin{array}{l}65.4 \% \\
(n=17)\end{array}$ & $\begin{array}{l}11.5 \% \\
(n=3)\end{array}$ & $\begin{array}{l}15.4 \% \\
(n=4)\end{array}$ & $\begin{array}{l}7.7 \% \\
(n=2)\end{array}$ & $p=0.717$ \\
\hline $\begin{array}{l}\text { M. sternocleidomastoideus } \\
\text { left } 2^{\text {nd }}\end{array}$ & $\begin{array}{l}61.5 \% \\
(n=16)\end{array}$ & $\begin{array}{l}11.5 \% \\
(n=3)\end{array}$ & $\begin{array}{l}19.2 \% \\
(n=5)\end{array}$ & $\begin{array}{l}7.7 \% \\
(n=2)\end{array}$ & $\begin{array}{l}53.8 \% \\
(n=14)\end{array}$ & $\begin{array}{l}7.7 \% \\
(n=2)\end{array}$ & $\begin{array}{l}26.9 \% \\
(n=7)\end{array}$ & $\begin{array}{l}11.5 \% \\
(n=3)\end{array}$ & $p=0.752$ \\
\hline M. trapezius right $1^{\text {st }}$ & $\begin{array}{l}61.5 \% \\
(n=16)\end{array}$ & $\begin{array}{l}26.9 \% \\
(n=7)\end{array}$ & $\begin{array}{l}7.7 \% \\
(n=2)\end{array}$ & $\begin{array}{l}3.8 \% \\
(n=1)\end{array}$ & $\begin{array}{l}53.8 \% \\
(n=14)\end{array}$ & $\begin{array}{l}23 \% \\
(n=6)\end{array}$ & $\begin{array}{l}19.2 \% \\
(n=5)\end{array}$ & $\begin{array}{l}3.8 \% \\
(n=1)\end{array}$ & $p=0.842$ \\
\hline M. trapezius right $2^{\text {nd }}$ & $\begin{array}{l}69.2 \% \\
(n=18)\end{array}$ & $\begin{array}{l}11.5 \% \\
(n=3)\end{array}$ & $\begin{array}{l}7.7 \% \\
(n=2)\end{array}$ & $\begin{array}{l}11.5 \% \\
(n=3)\end{array}$ & $\begin{array}{l}50 \% \\
(n=13)\end{array}$ & $\begin{array}{l}7.7 \% \\
(n=2)\end{array}$ & $\begin{array}{l}26.9 \% \\
(n=7)\end{array}$ & $\begin{array}{l}15.4 \% \\
(n=4)\end{array}$ & $p=0.324$ \\
\hline M. trapezius right $3^{\text {rd }}$ & $\begin{array}{l}80.8 \% \\
(n=21)\end{array}$ & $\begin{array}{l}3.8 \% \\
(n=1)\end{array}$ & $\begin{array}{l}7.7 \% \\
(n=2)\end{array}$ & $\begin{array}{l}7.7 \% \\
(n=2)\end{array}$ & $\begin{array}{l}73.1 \% \\
(n=19)\end{array}$ & $\begin{array}{l}7.7 \% \\
(n=2)\end{array}$ & $\begin{array}{l}11.5 \% \\
(n=3)\end{array}$ & $\begin{array}{l}7.7 \% \\
(n=2)\end{array}$ & $p=0.286$ \\
\hline M. trapezius left 1 st & $\begin{array}{l}76.9 \% \\
(n=20)\end{array}$ & $\begin{array}{l}7.7 \% \\
(n=2)\end{array}$ & $\begin{array}{l}11.5 \% \\
(n=3)\end{array}$ & $\begin{array}{l}3.8 \% \\
(n=1)\end{array}$ & $\begin{array}{l}69.2 \% \\
(n=18)\end{array}$ & $\begin{array}{l}7.7 \% \\
(n=2)\end{array}$ & $\begin{array}{l}19.2 \% \\
(n=5)\end{array}$ & $\begin{array}{l}3.8 \% \\
(n=1)\end{array}$ & $p=0.478$ \\
\hline M. trapezius left $2^{\text {nd }}$ & $\begin{array}{l}69.2 \% \\
(n=18)\end{array}$ & $\begin{array}{l}7.7 \% \\
(n=2)\end{array}$ & $\begin{array}{l}15.4 \% \\
(n=4)\end{array}$ & $\begin{array}{l}7.7 \% \\
(n=2)\end{array}$ & $\begin{array}{l}50 \% \\
(n=13)\end{array}$ & $\begin{array}{l}30.8 \% \\
(n=8)\end{array}$ & $\begin{array}{l}7.7 \% \\
(n=2)\end{array}$ & $\begin{array}{l}11.5 \% \\
(n=3)\end{array}$ & $p=0.099$ \\
\hline M. trapezius left $3^{\text {rd }}$ & $\begin{array}{l}88.5 \% \\
(n=23)\end{array}$ & $\begin{array}{l}3.8 \% \\
(n=1)\end{array}$ & $\begin{array}{l}3.8 \% \\
(n=1)\end{array}$ & $\begin{array}{l}3.8 \% \\
(n=1)\end{array}$ & $\begin{array}{l}80.8 \% \\
(n=21)\end{array}$ & $\begin{array}{l}3.8 \% \\
(n=1)\end{array}$ & $\begin{array}{l}11.5 \% \\
(n=3)\end{array}$ & $\begin{array}{l}3.8 \% \\
(n=1)\end{array}$ & $p=0.459$ \\
\hline LS right 1 st & $\begin{array}{l}42.3 \% \\
(n=11)\end{array}$ & $\begin{array}{l}30.8 \% \\
(n=8)\end{array}$ & $\begin{array}{l}15.4 \% \\
(n=4)\end{array}$ & $\begin{array}{l}11.5 \% \\
(n=3)\end{array}$ & $\begin{array}{l}57.7 \% \\
(n=15)\end{array}$ & $\begin{array}{l}26.9 \% \\
(n=7)\end{array}$ & $\begin{array}{l}11.5 \% \\
(n=3)\end{array}$ & $\begin{array}{l}3.8 \% \\
(n=1)\end{array}$ & $p=0.403$ \\
\hline LS right $2^{\text {nd }}$ & $\begin{array}{l}61.5 \% \\
(n=16)\end{array}$ & $\begin{array}{l}7.7 \% \\
(n=2)\end{array}$ & $\begin{array}{l}19.2 \% \\
(n=5)\end{array}$ & $\begin{array}{l}11.5 \% \\
(n=3)\end{array}$ & $\begin{array}{l}57.7 \% \\
(n=15)\end{array}$ & $\begin{array}{l}19.2 \% \\
(n=5)\end{array}$ & $\begin{array}{l}19.2 \% \\
(n=5)\end{array}$ & $\begin{array}{l}3.8 \% \\
(n=1)\end{array}$ & $p=0.301$ \\
\hline LS left 1st & $\begin{array}{l}53.8 \% \\
(n=14)\end{array}$ & $\begin{array}{l}26.9 \% \\
(n=7)\end{array}$ & $\begin{array}{l}7.7 \% \\
(n=2)\end{array}$ & $\begin{array}{l}11.5 \% \\
(n=3)\end{array}$ & $\begin{array}{l}65.4 \% \\
(n=17)\end{array}$ & $\begin{array}{l}19.2 \% \\
(n=5)\end{array}$ & $\begin{array}{l}7.7 \% \\
(n=2)\end{array}$ & $\begin{array}{l}7.7 \% \\
(n=2)\end{array}$ & $p=0.615$ \\
\hline LS left $2^{\text {nd }}$ & $\begin{array}{l}69.2 \% \\
(n=18)\end{array}$ & $\begin{array}{l}11.5 \% \\
(n=3)\end{array}$ & $\begin{array}{l}7.7 \% \\
(n=2)\end{array}$ & $\begin{array}{l}11.5 \% \\
(n=3)\end{array}$ & $\begin{array}{l}61.5 \% \\
(n=16)\end{array}$ & $\begin{array}{l}15.4 \% \\
(n=4)\end{array}$ & $\begin{array}{l}11.5 \% \\
(n=3)\end{array}$ & $\begin{array}{l}11.5 \% \\
(n=3)\end{array}$ & $p=0.396$ \\
\hline
\end{tabular}

\section{Ethics}

Ethics Committee Approval: Approval was obtained from the İstanbul University-Cerrahpaşa, Cerrahpaşa Faculty of Medicine Ethics Committee (date: 07.03.2016, approval no: 89638). Informed Consent: Written consent forms were obtained. Peer-review: Externally and internally peer-reviewed.

\section{Authorship Contributions}

Surgical and Medical Practices: O.S., Z.Ü.A., Concept: O.S., Z.Ü.A., Design: O.S., Z.Ü.A., Data Collection or Processing: O.S., Z.Ü.A., Analysis or Interpretation: O.S., Z.Ü.A., Literature Search: O.S., Z.Ü.A., Writing: O.S., Z.Ü.A.

Conflict of Interest: No conflict of interest was declared by the authors.

Financial Disclosure: The authors declared that this study received no financial support.

\section{References}

1. Hoy DG, Protani M, De R, Buchbinder R. The epidemiology of neck pain. Best Pract Res Clin Rheumatol 2010;24:783-92.

2 Jagdhari BS, Mukta M, Saket AG, Golhar AV. Therapeutic Evaluation of Cervical Dysfunction in Patients with Myofascial Pain Dysfunction Syndrome: A Prospective Study. J Contemp Dent Pract 2017;18:601-6

3. Simons DG, Travell JG. Travell \& Simons' Myofascial Pain and Dysfunction: The Trigger Point Manual : Volume 1: Upper Half of Body. Philadelphia: Lippincott Williams andWilkins; 1998. p. 183200,202-217, 334-342

4. Parthasarathy S, Sundar S, Mishra G. Assessment of predisposing factors in myofascial pain syndrome and the analgesic effect of trigger point injections - A primary therapeutic interventional clinical trial. Indian J Anaesth 2019;63:300-3.

5. Hansraj KK. Assessment of stresses in the cervical spine caused by posture and position of the head. Surg Technol Int 2014;25:277-9.

6. Neupane S, Ali UTI, Mathew A. Text Neck Syndrome - Systematic Review 2017;3:8

7. Fares J, Fares MY, Fares Y. Musculoskeletal neck pain in children and adolescents: Risk factors and complications. Surg Neurol Int 2017;8:72. 
8. Gustafsson E, Thomée S, Grimby-Ekman A, Hagberg M. Texting on mobile phones and musculoskeletal disorders in young adults: A five-year cohort study. Appl Ergon 2017;58:208-14.

9. Berolo S, Wells RP, Amick BC. Musculoskeletal symptoms among mobile hand-held device users and their relationship to device use: A preliminary study in a Canadian university population. Appl Ergon 2011;42:371-8.

10. Samani PP, Athavale NA, Shyam A, Sancheti PK. Awareness of text neck syndrome in young-adult population. Int J Community Med Public Health 2018;5:3335.

11. Brandt M, Sundstrup E, Jakobsen MD, Jay K, Colado JC, Wang Y, et al. Association between Neck/Shoulder Pain and Trapezius Muscle Tenderness in Office Workers. Pain Res Treat 2014;2014:352735.

12. Aksoy E. The Correlation Between Cervical Misalignment, Chronic Cervical Pain and Trigger Point (thesis). Istanbul:2015 istanbul Üniv; 2015.

13. Kanchanomai $S$, Janwantanakul $P$, Pensri $P$, Jiamjarasrangsi W. Risk factors for the onset and persistence of neck pain in undergraduate students: 1-year prospective cohort study. BMC Public Health 2011;11:566.

14. Hush JM, Michaleff Z, Maher CG, Refshauge K. Individual, physical and psychological risk factors for neck pain in Australian office workers: a 1-year longitudinal study. Eur Spine J 2009;18:1532-40.

15. Xie Y, Szeto G, Dai J. Prevalence and risk factors associated with musculoskeletal complaints among users of mobile handheld devices: A systematic review. Appl Ergon 2017;59:132-42.

16. Hegazy A, Alkhail B, Awadalla N, Qadi M, Al-Ahmadi J. Mobile Phone Use and Risk of Adverse Health Impacts among Medical Students in Jeddah, Saudi Arabia. BJMMR 2016;15:1-11.

17. Shan Z, Deng G, Li J, Li Y, Zhang Y, Zhao Q. Correlational analysis of neck/shoulder pain and low back pain with the use of digital products, physical activity and psychological status among adolescents in Shanghai. Milanese $\mathrm{S}$, editor. PLoS One 2013;8:e78109. doi: 10.1371/journal.pone.0078109 eCollection 2013.

18. Kim HJ, Kim JS. The relationship between smartphone use and subjective musculoskeletal symptoms and university students. J Phys Ther Sci 2015;27:575-9.

19. Alzarea BK, Patil SR. Mobile phone head and neck pain syndrome: Proposal of a New Entity. OHDM 2015;14:5.
20. Gold JE, Driban JB, Thomas N, Chakravarty T, Channell V, Komaroff E. Postures, typing strategies, and gender differences in mobile device usage: An observational study. Appl Ergon 2012;43:408-12.

21. Falla $D$, Jull G, Russell $T$, Vicenzino $B$, Hodges P. Effect of neck exercise on sitting posture in patients with chronic neck pain. Phys Ther 2007;87:408-17.

22. Kim SY, Koo SJ. Effect of duration of smartphone use on muscle fatigue and pain caused by forward head posture in adults. J Phys Ther Sci 2016;28:1669-72.

23. Syamala KR, Ailneni RC, Kim JH, Hwang J. Armrests and back support reduced biomechanical loading in the neck and upper extremities during mobile phone use. Appl Ergon 2018;73:48-54.

24. Kong YS, Kim Y-M, Shim J. The effect of modified cervical exercise on smartphone users with forward head posture. J Phys Ther Sci 2017;29:328-31.

25. Park J, Kim J, Kim J, Kim K, Kim N, Choi I, et al. The effects of heavy smartphone use on the cervical angle, pain threshold of neck muscles and depression. 2015.

26. Öğrenci A, Koban O, Yaman O, Dalbayrak S, Yılmaz M. The effect of technological devices on cervical lordosis. Open Access Maced J Med Sci [Internet]. 2018. Available from: https://www.id-press. eu/mjms/article/view/oamjms.2018.107

27. Hong C-Z. Considerations and recommendations regarding myofascial trigger point injection. J Musculoskeletal Pain 1994;2:29-59.

28. Fernández-de-las-Peñas C, Alonso-Blanco C, Miangolarra JC. Myofascial trigger points in subjects presenting with mechanical neck pain: A blinded, controlled study. Man Ther 2007;12:29-33.

29. Jaeger B, Reeves JL. Quantification of changes in myofascial trigger point sensitivity with the pressure algometer following passive stretch. Pain 1986;27:203-10. 